Kirja-arvio

\title{
Inspiroivaa tutkimusretkeilyä osallisuuden rajapinnoilla
}

Hieta, Hanneleena, Karri Kiiskinen, Maija Mäki, Päivi Roivainen ja AnnHelen Sund (toim.). 2019. Liikettä rajapinnoilla - keskusteluja etnologian osallistavuudesta: Rörelser och gränsytor - etnologiska diskussioner om samverkan. Helsinki: Suomen kansatieteilijöiden yhdistys Ethnos ry. 398 sivua. http://urn.fi/URN:NBN:fi-fe2020102185858

\section{Salome Tuomaala-Özdemir}

$\mathrm{H}$ anneleena Hiedan, Karri Kiiskisen, Maija Mäen, Päivi Roivaisen ja Ann-Helen Sundin toimittama Liikettä rajapinnoilla - Rörelser och gränsytör esittelee alaotsikkonsa mukaisesti keskusteluja etnologian osallisuudesta, kahdella kielellä. Vuonna 2019 ilmestyneessä artikkelikokoelmassa tutkijat retkeilevät pyöräilyn ja katueläinten tutkimuksesta kasviperintöprosesseihin ja kohtaamisiin ruhnulaisen villapaidan kanssa museokontekstissa. Julkaisussa pirskahtelee tutkimuksen into ja ilo, joihin itsekin yhteisösuhteiden osallisuuden tutkijana tempauduin lukiessa mukaan. Mieltäni lämmittivät kahdentoista artikkelin kuvaukset kohtaamisista tutkittavien kanssa, olipa tutkittava sitten pyöräiltävä reitti, raumalainen laivanrakentaja, rodoslainen katukissa, yläneläinen Huvitus-omena tai

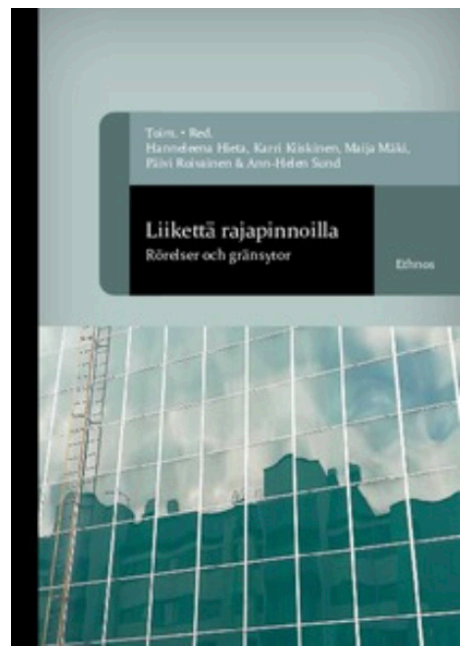
suhteestaan siihen kertova haastateltava. Niin ihmisillä, eläimillä ja kasveilla kuin paikoilla ja esineilläkin on maailmansa, joiden ääreen, ääneen ja rytmeihin osallistava etnologia kirjassa johdattaa. Teos on jaettu kahteen osaan, joista ensimmäinen on otsikoitu "Tutkimus: Osallistuminen, osallistavuus ja soveltavuus" ja toinen "Jakaminen: Tiedon siilot ja vastavuoroisuuden väylät". Arvostelussani paneudun pohtimaan erityisesti niitä artikkeleita, jotka puhuttelivat ajankohtaisuudellaan. Lisäksi arvioin kirjaa kokonaisuutena.

\section{Itsereflektio tutkijan kompassina}

Osallistavuudesta ja osallisuudesta on viimeisen kymmenen vuoden aikana tullut iskusanoja tutkimuksen lisäksi myös yhteiskunnassa yleisemmin. Yhteiskunnallinen osallisuus tarkoittaa ihmisen kiinnittymistä itselle merkityksellisiin yhteisöihin ja sitä myöten sellaiseen yhteiskunnalliseen toimintaan, jonka kautta voi sekä tyydyttää perustavanlaatuisia tarpeitaan että 
toteuttaa itseään ja tuntea kuuluvansa johonkin. Osallisuuden hyvän tarkoituksen voi myös valjastaa politiikkapuheen moottoriksi, tuottamaan kiireisiä projekteja, jotka osallisuuden syventämisen sijasta ottavat ihmiset tai alueet hankkeiden objekteiksi. Tämän ongelman nostavat esiin myös Tytti Steel ja Eerika Koskinen-Koivisto artikkelissaan "Läsnäolevaa ja sitoutunutta. Osallistumisen hyöty ja mielekkyys etnologisessa tutkimuksessa". He kuvaavat pätkärahoituksen tuottamia lyhyitä kenttätyöjaksoja ja innovaatiokeskeistä tutkijanuran mallia, jossa syventyvää tutkimusta harvoin palkitaan. Toisinaan osallisuushypetyksellä tuotetut pikainterventiot jättävätkin jälkeensä lähinnä turhautumista osallistavuuden ja osallisuuden ideoihin. Siksi niin yhteiskunnallisissa hankkeissa kuin tutkimuksessakin on olennaista tietää mitä, miten ja miksi lähdetään tekemään, kun pakataan varusteita osallisuuden retkelle.

Koska osallisuus syntyy aina suhteissa, on suhteen eri osapuolille annettava mahdollisuuksia ja välineitä muutokseen. Tutkimuksessa tämä tarkoittaa, että osallistumisen mahdollisuuden tarjoaminen tutkittaville ei riitä. Kuten aihetta kirjan johdannossa avaavat Karri Kiiskinen ja Hanneleena Hieta toteavat: tutkimus osallistaa myös tutkijan itsensä. Myös tutkijan ja tutkimuksen on siis muututtava. Tarvittavien muutosten ajatteluun ja konkreettiseen tekemiseen kirja tarjoaa pohdintaa ja esimerkkejä keinoista.

Yhtenä tärkeimmistä keinoista tutkijan lähestymistavan muutokselle nostetaan esiin tiedon ja tietämisen moninaisuus sekä erityisesti ruumiillinen ja kokemuksellinen tieto. Karri Kiiskisen kertomus pyöräilystä liikkuvana aluetutkimuksena ja Sanna Lillbroända-Annalan kuvaus kiinnittymisestä katueläinten elämismaailmaan toimivat esimerkkeinä siitä, että ruumiillista ja kokemuksellista tietoa voi kertyä ja kerryttää useammalla kuin yhdellä tavalla. Kiiskisen omat kokemukset reittien pyöräilystä yhdistettynä GPS-reittijälkien tuottamaan dataan avaavat niin alueen hahmottamista liikkeen ja rytmin kautta kuin vuorovaikutusta ja näkymiä toisten pyöräilijöiden kokemusten ytimeen. Lillbröanda-Annala puolestaan kuvaa lomamatkan muuttumista tunteelliseksi ja käytännölliseksi suhteeksi katueläimiin sekä tunteiden ja käytäntöjen tuottamia muutoksia tutkimukseen. Kiiskisen ja Lillbröanda-Annalan erilaisille lähestymistavoille on yhteistä oman kokemusten ja toiminnan havainnointi. Sekä suorien havaintojen tuottamaa että itsereflektion syventämää tietoa voi käyttää vuorovaikutuksen lisäämiseen toisten - ihmisten, eläinten ja ympäristön - kanssa. Tällaiset tiedonhankinnan tavat ja niiden huolellinen, konkreettinen kuvaaminen lisäävät myös tekstin elämyksellisyyttä. Elämyksellisyys tuo tutkimuksen lähemmäksi lukijaa ja suo aiheesta kiinnostuneelle ja tietävälle lukijalle mahdollisuuden nauttia tutkimuksen tuloksista, riippumatta siitä, onko hän kuvatun tutkimusalan asiantuntija vai ei.

\section{Ymmärrettävän yhteistietämisen eväät}

Analyysin lähestyttävyyttä ja ymmärrettävyyttä voi pitää osallistavan tutkimuksen tavoitteena. Lisäämällä tutkimustekstin saavutettavuutta otetaan askeleita kohti Kristiina Ahmaksen artikkelissaan kuvaamaa avointa asiantuntijuutta ja yhteistä tietämistä. Itselleni osallisuuden tutkijana artikkelien analyysit avautuivat enimmäkseen kertalukemalla. Yksi editointikierros yleistajuisen ilmaisun näkökulmasta olisi kuitenkin avannut tekstiä laajemmalle lukijakunnalle, myös niille lukuisille ihmisille, joita teksteissä kuvataan tutkimusten osallistujina ja kanssatutkijoina ja joista todennäköisesti vain harvalla on tutkijan koulutus. Yleistajuisen tekstin tuottamisen ei tarvitse tarkoittaa tutkimuspainotuksista tai käsitteellisestä pohdinnasta luopumista. Monesti käsitteiden tarkempi avaaminen ja tekstin tarkistaminen selkeyden näkökulmasta riittävät, kun teksti tahdotaan tehdä luettavaksi myös tutkijapiirien ulkopuolelle. 
Liikettä rajapinnoilla - Rörelser och gränsytor laventaa kirjan lukijakuntaa suomenkielistä yleisöä laajemmalle tarjoamalla johdannon ja yhden tutkimusta esittelevän artikkelin ruotsiksi. Ruotsinkieliselle lukijalle kaksikielinen otsikko tarjoaa lupauksen, jonka kirjan ruotsinkielisen osuuden ohuus saattaa kuitenkin pettää. Mielestäni kirjan kaksikielisyyttä olisikin voinut perustella selvemmin kirjan johdannossa. Monikielinen julkaiseminen on nimittäin käytäntö, jota tutkimuksen osallisuutta edistäessä olisi syytä pohtia ja harjoittaa enemmän, niin virallisten kotimaisten kielten kuin uusien suomalaisten puhumien kieltenkin osalta. Osallisuuden näkökulmasta jäin kaipaamaan myös yhteiskirjoitettuja tekstejä tutkimukseen osallistuneiden amatööriasiantuntijoiden kanssa. Erinomaisesti valitut lainaukset heidän puheestaan ja kirjoittamistaan teksteistä kuitenkin paikkasivat tätä puutetta.

Kirjan tarjoaman tiedon saavutettavuus ei ole tärkeää ainoastaan kuvattuihin tutkimuksiin osallistuneiden palvelemiseksi. Hiilivapaa liikkuminen, kasviperintö, lajienvälisyys, lähimatkailu ja yhteisöjä vahvistava elävä suhde historian kertomuksiin ja käytäntöihin ovat ajankohtaisia aiheita. Ajankohtaisista teemoista riittää yhteisessä keskustelussa paljon puhetta. Osallisuutta lisäävä etnologia näyttäisi kirjan perusteella tarjoavan välineitä lisätä tietoa ja ymmärtää asioita paikallisesti ja yhdessä. Paikallinen ja yhteinen ymmärrys voisivat osaltaan auttaa etsimään konkreettisia ratkaisuja siedettävien jatkumoiden löytämiseksi ihmisten ja ympäristön yhteiseloon ja vuorovaikutukseen, joita koettelevat ilmastonmuutos ja yhteiskunnallisen keskustelun polarisaatiopainotukset ja tätä kirjoittaessa myös maailmanlaajuinen pandemia.

Artikkelikokoelma houkuttelee pohtimaan, miten pienistä ja kouriintuntuvista langanpäistä lokaalien ja maapallon kohtaloon liittyvien asioiden ratkaisuja voidaan lähteä kerimään. Teoksen ajankohtaista painoarvoa olisi lisännyt, jos näihin langanpäihin olisi lisätty vähintään yhden artikkelin verran teknologisten sovellusten merkitysten pohdintaa niin ihmisten arjen ja yhteisöllisyyden kuin tutkimuksen tekemisen käytäntöjenkin näkökulmista. Nyt teknologia jää teoksessa valitettavasti sivurooliin.

Ympäristön kestävyys ei ole irrallaan sosiaalisesta maailmasta vaan sen keskiössä. Osallisuuden laadukas ja monipuolinen kehittäminen tutkimuksessa voi tuoda tämän näkyviin valottamalla ihmisten, eläinten, kasvien, rakennetun tilan ja ympäristön dynaamisia suhteita ja niiden merkityskerrostumia. Paikallisista havainnoista ponnistava, herkästi ympäristöä aistiva ja tunnusteleva, merkityksellistä yhteisöllisyyttä ja yhteistietämistä vahvistava tutkimus voi parhaimmillaan yhdistää inmisiä, poimia käyttökelpoisia sanoja ja käytäntöjä menneestä sekä näyttää valoa yhdessä etenemiseen. Jäinkin kaipaamaan johtopäätösartikkelia, joka olisi koonnut kirjan teemoja selkeämmin yhteen ja nostanut esiin niiden yhteiskunnallista painoarvoa. Näistä samoista syistä kirjan viehättävistä tutkimusaiheista olisi syytä koota joko kokonaan uusi tietokirja suurelle yleisölle tai vaikka sarja keskustelevia podcasteja, jotta esiteltyjen tutkimusten arvo tulisi vielä paremmin näkyviin ja eri tavoin tietoa vastaanottavien ihmisten saataville.

FT Salome Tuomaala-Özdemir on erikoistutkija Turun yliopiston sosiologian laitoksella. 